\title{
Article
}

\section{Twitterati and Paperati - evidence versus popular opinion in science communication}

MacNamara, Á., and Collins, D.

Available at https://clok.uclan.ac.uk/12460/

MacNamara, Á., orcid iconORCID: 0000-0002-8110-6784 and Collins, D. orcid iConORCID: 0000-0002-7601-0454 (2015) Twitterati and Paperati - evidence versus popular opinion in science communication. British Journal of Sports Medicine, 49 (19). pp. 1227-1228. ISSN 0306-3674

It is advisable to refer to the publisher's version if you intend to cite from the work. http://dx.doi.org/10.1136/bjsports-2015-094884

For more information about UCLan's research in this area go to http://www.uclan.ac.uk/researchgroups/ and search for <name of research Group>.

For information about Research generally at UCLan please go to http://www.uclan.ac.uk/research/

All outputs in CLoK are protected by Intellectual Property Rights law, including Copyright law. Copyright, IPR and Moral Rights for the works on this site are retained by the individual authors and/or other copyright owners. Terms and conditions for use of this material are defined in the policies page.

\section{CLoK}

Central Lancashire online Knowledge www.clok.uclan.ac.uk

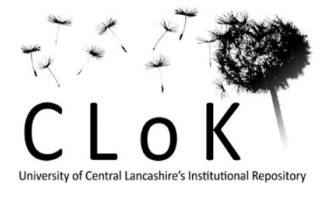


This is a pre-proof corrected manuscript, as accepted for publication, of an article published by BMJ

Publishing Group in British Journal of Sports Medicine on $23^{\text {rd }}$ April 2015, available online:

http://bjsm.bmj.com/content/early/2015/04/23/bjsports-2015-094884.extract

PLEASE REFER TO THE PUBLISHED VERSION FOR CITING PURPOSES

Editorial: Twitterati and Paperati - evidence versus popular opinion in science communication

Áine MacNamara* and Dave Collins

Institute of Coaching and Performance, University of Central Lancashire, Preston, UK

*Correspondence concerning this manuscript should be addressed to Áine MacNamara,

Greenbank Building, Institute of Coaching and Performance, University of Central Lancashire,

Preston, UK. Email: AMacnamara1@uclan.ac.uk 
Science communication has traditionally been the remit of peer-reviewed journals with information being shared, almost exclusively, within the academic community. For those working at the coalface the limited scope of this traditional discourse in terms of access and consumption by key stakeholders (e.g., coaches, National Governing Bodies of sport, sport scientists) is of concern. In fact, traditional peer-reviewed publication does not seem to be the most effective mechanism for scientists to engage with the public and to disseminate knowledge.

Reflecting these concerns is the trend to use social media to communicate science -- tools such as Twitter are an increasingly important part of the scholarly ecology[1,2] and a powerful influence on professional environments. However, the extent to which the information transmitted by social media is evidence - based rather than opinion, based is questionable. Of course, these concerns are not to say that the academic world should be the only gatekeepers of knowledge, but in a Web 2.0 world where knowledge is made available at a rapid rate, the peer review process does provide a level of rigour[3]. At the same time, the social media infrastructure affords greater information sharing and, therefore, may potentially have higher impact on the ground. The quality of the information is, of course, crucial; essentially, scholarly discourse should be disseminated with quality assurance and ideally unsubstantiated opinion would not see the light of day- more science, less sermon!

\section{Twitter as scientific communication?}

Platforms like Twitter afford the ability for both the scientific and applied community to access up-to-date information at the touch of a screen. However, the quality of this information, and 
equally importantly the balance of the information circulated, does not undergo any quality control. Indeed, the self-selection of information consumed by readers is illustrated here:

I soon learnt that Twitter is unquestionably the best way to acquire the most up-to-date information on my particular areas of scientific interest. By following a group of scientists who use Twitter to disseminate information they find interesting, I now have access to new knowledge within minutes of its first appearance in the scientific literature. The result is that acquiring new information is absolutely effortless, and dependent only on my choice of whom I follow on Twitter.[cited in 4]

The assumption is that consumers listen to the people who share tweets about things that appeal to them and therefore build up a shared community of individuals with similar opinions and, by virtue of preferential attachment[5], information gains credibility and traction in what Tremayne and colleagues[6] term a "rich get richer" fashion. In much the same manner, people with opposing opinions can be unfollowed (i.e. the tweets do not appear on the consumer's twitter feed) so that the consumer does not have to contend with conflicting evidence. Social media is founded on connections and relationships that promote information-sharing but, crucially and with significant potential for negative impact, in a self-selected manner[7]. Indeed, the ability to circulate ideas that are persistent and persuasive but potentially without evidence is a real danger[8]. The bottom line is that such communication must come with, at the very least, a health warning or, preferentially, a balancing argument. In fact, could distribution of "knowledge" without such be considered a Code of Conduct violation by professional organisations?

\section{Caveat emptor!}


Web 2.0 platforms are now at the forefront of knowledge dissemination. These tools have immense power to spread information quickly, influence people and perhaps even mobilise them to action. However, academics have a responsibility to ensure there is an evidence basis to the information that scholars share. This is especially important when consumers of this knowledge may be swayed by the authority (e.g., professional standing, accreditation, or certification) of those sharing information, a concentration of persuasive, (apparently) face valid but evidence lacking tweets, or the skills to filter the good from the bad.

It may well be that academics need to embrace these means of communication as without this change in how we disseminate knowledge, there is a danger that the academic community may become irrelevant to applied practice while, at the same time, popular (though perhaps unfounded) myths and practices gain momentum. There are a number of implications to this state of play but, for the moment, we should perhaps consider the duty of care for professional organisations (in our field, for example, British Association of Sport and Exercise Science (UK), British Psychology Society (UK), American College of Sports Medicine (USA)) to fulfil this balancing function. Of course, we have no wish to censor, but certainly a desire to see both sides of the coin consistently presented, even if this may prove challenging in 140 characters! We look forward to debate, unlike (perhaps) some of our tweeting colleagues!

\section{References}

1. Shuai X, Pepe A, Bollen J. How the scientific community reacts to newly submitted preprints: Article downloads, twitter mentions, and citations. PLoS ONE 2012;

7(11):e47523. DOI: 10.1371/journal.pone.0047523 
2. Verhagen E, Bower C, Khan KM. How BJSM embraces the power of social media to disseminate research. Br J Sports Med. 2014 Apr;48(8):680-1.

3. Spier R. The history of the peer-review process. Trends Biotechnol 2002; 20(8): 357-8. DOI: 10.1016/S0167-7799(02)01985-6

4. Rousseau J. Noakes, \#LCHF and the Professoriate of the Twitterati. Retrieved March 2015 from http://synapses.co.za/noakes-lchf-professoriate-twitterati

5. Lasorsa DL, Lewis SC, Holton AE. Normalizing twitter. Journal Stud 2012;13:19-36. doi:10.1080/1461670X.2011.571825

6. Tremayne, Zheng N, Lee, JK, Jeong J. Issues Publics on the web: applying network theory to the war blogosphere. J Comput Mediat Commun 2006;12: 290-310. DOI: 10.1111/j.1083-6101.2006.00326.x

7. Skoler M. Why the news media became irrelevant and how social media can help. Nieman Reports 2009. Retrieved March 2015 from http://jclass.umd.edu/classes/jour698m/skoler_files/contentserver.pdf

8. Collins D, Bailey R. "Scienciness" and the allure of second-hand strategy in talent development. International Journal of Sport Policy and Politics 2013; 5:183-191. DOI: $10.1080 / 19406940.2012 .656682$ 
